\title{
PENGEMBANGAN PERANGKAT PEMBELAJARAN IPA BERBASIS PENDEKATAN PENEMUAN TERBIMBING UNTUK MELATIHKAN KETERAMPILAN PROSES SISWA SEKOLAH DASAR
}

\author{
Agung Rimba Kurniawan, Soeparman Kardi, Tjandrakirana \\ Pendidikan Dasar, Pascasarjana Universitas Negeri Surabaya \\ email: unesa.agung@yahoo.com
}

\begin{abstract}
Abstrak
Telah dilakukan penelitian pengembangan perangkat pembelajaran IPA berbasis pendekatan penemuan terbimbing materi Gaya yang bertujuan untuk melatihkan keterampilan proses sains dan meningkatkan hasil belajar siswa kelas IV SD. Penelitian ini dilaksanakan dua tahap, yaitu : tahap pengembangan perangkat pembelajaran model Dick and Carey (2005) dan tahap pelaksanaan pembelajaran di kelas menggunakan rancangan One Group Pretest-Postest Design. Data dianalisis secara deskriptif kuantitatif-kualitatif.Hasil penelitian perangkat pembelajaran yang dikembangkan berkategori valid. Keterbacaan Materi Ajar Siswa sangat mudah dipahami. Keterlaksanaan Pembelajaran sangat baik (100\%). Aktivitas siswa sangat aktif (93.21\%) dengan tingkat realibilitas tinggi (0.98). Hasil belajar klasikal kognitif dan keterampilan proses siswa tuntas (100\%). NGain kategori tinggi hasil belajar kognitif (0.76) dan hasil belajar keterampilan proses (0.72). Respon siswa positif $(85.92 \%)$. Simpulan penelitian menunjukkan perangkat pembelajaran IPA berbasis pendekatan penemuan terbimbing layak untuk melatihkan keterampilan proses sains dan meningkatkan hasil belajar pada materi Gaya siswa kelas IV SD.
\end{abstract}

Kata Kunci: Pengembangan Perangkat Pembelajaran, Pendekatan Penemuan Terbimbing, dan Keterampilan Proses.

\begin{abstract}
The Study of instrument development of science learning was based on the discovery approachment, which was guided on the force topic. Aimed to train skills of science process and improve students' result of learning for fourth grade of elementary school.

This study was conducted in two phases, they were; development phase used Dick and Carey model (2005) and phase of learning implementation in the classroom used one group pretest-posttest design. Data were analyzed by descriptive quantitative-qualitative.

The result of study developed was valid category. Students Content Readability were very easy to be understood. The learning implementation was very well (100\%). The students' activities were very high (93.21\%) with a high level of reliability (0.98). The results of classical study and students' cognitive skills were completed (100\%). $N$ Gain cognitive achievement was the highest category (0.76) and process learning skills were (0.72). The students' respons were positive (85.92\%). The Conclusions of the research, instrument development of science learning was based on the discovery approachment, which was guided on the force topic matched to train skills of science process and improve students' result of learning for fourth grade of elementary school.
\end{abstract}

Keywords: Development of Learning Instrument, Guided Discovery Approach, and Process Skills.

\section{PENDAHULUAN}

IPA merupakan suatu kumpulan teori yang sitematis, penerapannya secara umum terbatas pada gejala-gejala alam, lahir dan berkembang melalui metode ilmiah seperti observasi dan eksperimen serta menuntut sikap ilmiah seperti rasa ingin tahu, terbuka, jujur dan sebagainya (Trianto, 2010:136).

Berdasarkan hasil observasi pada siswa kelas IV sejumlah 42 orang, menunjukkan hasil belajar pada pelajaran IPA saat ini mengalami masalah yaitu belum mencapai standar ketuntasan minimum. Sebanyak 24 atau 57,14 \% siswa mengikuti remedi pada materi Daur Makhluk Hidup karena belum memenuhi standar ketuntasan minimum yang ditetapkan yaitu $\geq 75$. Rendahnya hasil belajar disebabkan siswa belum mampu menguasai konsep pelajaran IPA, kurangnya penerapan keterampilan proses dikarenakan perangkat pembelajaran yang diterapkan di kelas belum sepenuhnya melatihkan keterampilan proses. Hal ini selaras dengan hasil penelitian Nanik Kusumawati (2014:4). Hasil penelitian menunjukkan bahwa keterampilan proses dasar IPA pada 33 siswa kelas V SD masih kurang, terbukti hanya sebesar $37,5 \%$ siswa yang mempunyai keterampilan proses dasar mengamati atau 
observasi, hanya $25 \%$ mengkomunikasikan dan inferensi, sebesar 68,75 \% siswa mampu mengklasifikasi. Hal ini menunjukkan bahwa perlu dilatihkan keterampilan proses IPA yang terencana dengan baik.

Keterampilan proses perlu dilatihkan karena sesuai dengan penegasan KTSP bahwa IPA berkaitan dengan cara mencari tahu tentang alam secara sistematis, sehingga IPA bukan hanya penguasaan kumpulan pengetahuan fakta-fakta, konsep-konsep, pinsip-prinsip saja tetapi juga merupakan suatu proses penemuan. Pendidikan IPA di sekolah dasar diharapkan dapat menjadi wahana bagi siswa untuk mempelajari diri sendiri dan alam sekitarnya. Pencapaian Standar Kompetensi dan Kompetensi Dasar didasarkan pada pemberdayaan peserta didik untuk membangun kemampuan, bekerja ilmiah, dan pengetahuan sendiri yang difasilitasi oleh guru (BNSP, 2006:161).

Menurut Dahar (dalam Devi, 2010:40) keterampilan proses perlu dilatihkan/dikembangkan dalam pengajaran sains karena keterampilan proses mempunyai peran sebagai berikut : membantu siswa belajar mengembangkan pikirannya, memberi kesempatan siswa untuk melakukan penemuan, meningkatkan daya ingat, memberikan kepuasan instrinsik bila anak telah berhasil melakukan sesuatu, membantu siswa mempelajari konsepkonsep sains.

Menurut Bruner (dalam Cooney \& Davis, 1975:138) penemuan adalah suatu proses. Proses penemuan dapat menjadi kemampuan umum melalui latihan pemecahan masalah, praktek membentuk dan menguji hipotesis. Bruner mengatakan belajar penemuan adalah belajar untuk menemukan, di mana seorang siswa dihadapkan dengan suatu masalah atau situasi yang tampaknya ganjil sehingga siswa dapat mencari jalan pemecahan.

Pembelajaran dengan penemuan merupakan satu komponen penting dalam pendekatan konstruktivis. Ide-ide konstruktivis moderen banyak berlandaskan pada teori Piaget dan Vygotsky yang digunakan untuk menunjang metode pengajaran yang menekankan pada pembelajaran kooperatif, pembelajaran berbasis kegiatan, dan penemuan (Nur, 2008:4). Salah satu prinsip teori Vygotsky yaitu Pemagangan Kognitif. Prinsip ini mengacu pada proses siswa tahap demi tahap mencapai kepakaran dalam interaksinya dengan seorang pakar, apakah seorang dewasa atau teman sebaya yang lebih tinggi pengetahuannya.
Hubungan antara materi gaya dengan pendekatan penemuan terbimbing dan keterampilan proses yaitu pada materi gaya lebih banyak kegiatan yang memungkinkan untuk melakukan sebuah percobaan langsung untuk membuktikan sebuah konsep gaya, sehingga dengan pendekatan penemuan terbimbing ini dapat menyajikan dan memberikan kemudahan kepada siswa untuk melakukan penyelidikan. Siswa dapat menemukan konsep tentang materi gaya dengan bimbingan guru melalui kegiatan-kegiatan dalam keterampilan proses. Bimbingan guru juga memungkinkan siswa dapat menggali informasi dengan memberikan kesempatan siswa bertanya, sehingga pengetahuan dan keterampilan yang didapatkan siswa diharapkan tidak dengan jalan mengingat seperangkat fakta-fakta, tetapi dengan jalan menemukan sendiri sebagai hasil kemandiriannya.

Hasil penelitian terdahulu menyatakan pembelajaran penemuan terbimbing serta perangkatnya efektif meningkatkan hasil belajar dan keterampilan proses sains siswa pada konsep sistem pernapasan (Handayani.S.A, 2012). Pembelajaran penemuan terbimbing dapat melatihkan keterampilan proses dan memberi peluang kepada siswa melakukan proses berpikir untuk menemukan konsep (Lutfiandari.A, 2013). Pembelajaran penemuan terbimbing efisien memperkuat pemikiran kreatif siswa. Signifikan dalam menumbuhkan kreativitas, fluiditas , fleksibilitas dan pengembangan kelompok eksperimen (Ali. G, 2013). Udo, Mfon Effiong (2010) merekomendasikan guru kimia di sekolah menengah bahwa penggunaan metode penemuan terbimbing dan demonstrasi yang berpusat pada siswa membuat efektif dalam berkomunikasi konsep kimia dan menanamkan keterampilan kewirausahaan yang relevan.

Berdasarkan hasil observasi juga ditemukan bahwa guru belum melakukan pengembangan perangkat pembelajaran untuk melatihkan keterampilan proses sains pada siswa. Sehingga perlu dilakukan pengembangan perangkat pembelajaran untuk meningkatkan efektivitas hasil belajar siswa dan melatihkan keterampilan proses sains pada siswa.

Abruscato Joseph (1996:40-49) secara garis besar mengemukakan bahwa keterampilan proses IPA dibagi menjadi dua yaitu (1) Keterampilan proses dasar dan (2) keterampilan proses terintegrasi. Keterampilan proses dasar meliputi : (a) observasi, (b) hubungan antara ruang dan waktu, 
(c) penggunaan angka, (d) klasifikasi, (e) mengukur, (f) mengkomunikasikan, (g) prediksi dan (h) menyimpulkan. Ketrampilan proses terintegrasi meliputi : (a) pengendalian variabel, (b) interpretasi, (c) merumuskan hipotesis, (d) definisi operasional, dan (e) eksperimen.

Menurut Nur (1996), enam keterampilan proses dasar yang perlu dilatihkan kepada siswa adalah : pengamatan, pengukuran, klasisifikasi, komunikasi, prediksi dan inferensi. Keenam keterampilan proses dasar ini merupakan prasarat untuk keterampilan proses terpadu. Seluruh keterampilan proses ini diperlukan apabila seseorang sedang berupaya menemukan pemecahan atas suatu masalah ilmiah. Keterampilan proses terpadu khususnya diperlukan apabila seseorang melakukan eksperimen untuk memecahkan masalah. Keterampilan proses terpadu yang penting dilatihkan meliputi ; identifikasi variabel, pengontrolan variabel, interpretasi data, perumusan hipotesis, perumusan definisi operasional variabel, perencanaan dan pelaksanaan eksperimen.

Dimyati dan Mudjiono (2002:138) memuat ulasan pendekatan keterampilan proses yang diambil dari pendapat Funk (1985) yaitu : (1) Pendekatan keterampilan proses dapat mengembangkan hakikat ilmu pengetahuan siswa. Siswa terdorong untuk memperoleh ilmu pengetahuan dengan baik karena lebih memahami fakta dan konsep ilmu pengetahuan; (2) Pembelajaran melalui keterampilan proses akan memberikan kesempatan kepada siswa untuk bekerja dengan ilmu pengetahuan, tidak hanya menceritakan, dan atau mendengarkan sejarah ilmu pengetahuan; (3) Keterampilan proses dapat digunakan oleh siswa untuk belajar proses dan sekaligus produk ilmu pengetahuan.

Menurut Dimyati (2009), Keterampilan Proses memiliki beberapa kelebihan diantaranya adalah :

a. Keterampilan Proses memberikan rangsangan ilmu pengetahuan, sehingga siswa dapat memahami fakta dan konsep ilmu pengetahuan dengan baik.

b. Memberikan kesempatan siswa bekerja dengan ilmu pengetahuan, tidak sekedar menceritakan atau mendengarkan cerita tentang ilmu pengetahuan.

c. Keterampilan Proses membuat siswa menjadi belajar proses dan produk ilmu pengetahuan sekaligus. Hal ini menyebabkan siswa menjadi lebih aktif.
Model Dick and Carey adalah model desain Instruksional yang dikembangkan oleh Walter Dick, Lou Carey dan James O Carey. Model ini adalah salah satu dari model prosedural, yaitu model yang menyarankan agar penerapan prinsip disain instruksional disesuaikan dengan langkahlangkah yang harus di tempuh secara berurutan.

Model Dick and Carey tertuang dalam bukunya The Systematic Design of Instruction edisi 6 tahun 2005. Perancangan instruksional menurut sistem pendekatan model Dick \& Carey terdapat beberapa komponen yang akan dilewati di dalam proses pengembangan dan perencanaan tersebut. Langkahnya ditunjukkan pada gambar berikut ini :

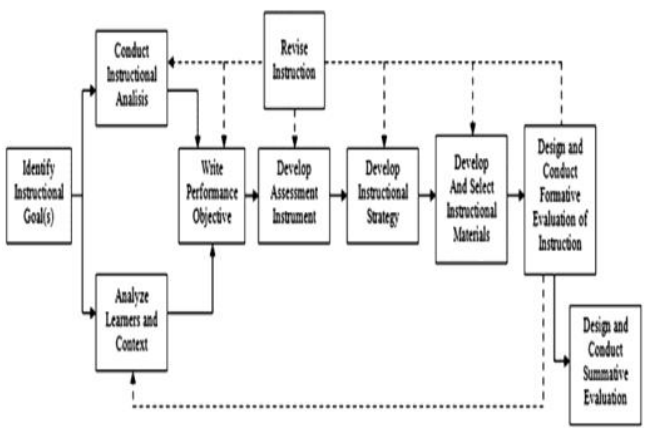

Gambar 1. Model Desain Sistem Instruksional dari Dick and Carey (2000)

\section{METODE}

Penelitian ini merupakan penelitian pengembangan (Development research), karena mengembangkan perangkat pembelajaran yang terdiri dari Silabus, RPP (Rencana Pelaksanaan Pembelajaran), LKS (Lembar Kegiatan Siswa), MAS (Materi Ajar Siswa) dan THB (Tes Hasil Belajar). Penelitian pengembangan ini dilaksanakan untuk menghasilkan perangkat pembelajaran berbasis penemuan terbimbing melatihkan keterampilan proses sains yang selanjutnya akan diujicobakan di kelas IV SD.

Sasaran penelitian adalah perangkat pembelajaran dengan pendekatan penemuan terbimbing untuk melatihkan keterampilan proses pada materi Gaya yang diujicobakan pada uji coba terbatas terhadap 10 orang siswa dan uji coba lapangan melibatkan 25 orang siswa di kelas IV SDN Pagerwojo.

Penelitian ini direncanakan di SDN Pagerwojo semester 2 tahun pelajaran 2014/2015. Kegiatan penelitian pada setiap uji coba dilaksanakan dalam 5 kali pertemuan, dengan rincian : 1 kali pertemuan untuk pretest, 3 kali pertemuan untuk kegiatan pembelajaran dan 1 kali pertemuan untuk postest. 
Prosedur atau langkah-langkah dalam penelitian ini meliputi tiga tahap utama yaitu : Pengembangan perangkat, validasi perangkat dan uji coba lapangan. Model pengembangan yang digunakan mengacu pada pengembangan perangkat pembelajaran Dick dan Carey (2005).

Pemilihan model Dick dan Carey pada prinsipnya relevan dengan KTSP. Hal ini sesuai dengan kutipan Ibrahim (2003). Selanjutnya peneliti mengadaptasi model pengembangan berdasarkan pada ketentuan dan kebutuhan dalam KTSP yang memiliki otoritas penuh dan tanggung jawab dalam menetapkan kurikulum. Pembelajaran sesuai dengan visi, misi, dan tujuan satuan pendidikan.

\section{DISKUSI DAN HASIL PENELITIAN}

Hasil penelitian ini adalah perangkat pembelajaran IPA yang layak untuk melatihkan keterampilan proses sains serta ikut meningkatkan hasil belajar IPA siswa kelas IV SD pada materi Gaya. Perangkat yang dikembangkan meliputi Silabus, Rencana Pelaksanaan Pembelajaran (RPP), Lembar Kerja Siswa (LKS), Materi Ajar Siswa (MAS), Tes Hasil Belajar (THB).

Berdasarkan hasil validasi yang dilakukan oleh pakar ahli menunjukkan bahwa kelayakan perangkat pembelajaran yang dikembangkan dapat dikatakan valid karena nilai validitas perangkat $3,60 \leq \mathrm{SV} \leq 4,59$ dan Reliable karena nilai realibilitas telah melewati batas minimal yang ditetapkan yaitu $(r) \geq 0.75$.

Menurut saran validator, silabus dapat digunakan dengan sedikit revisi. Revisi dilakukan untuk perbaikan pada penyesuaian tujuan pembelajaran dan indikator sehingga layak untuk diujicobakan. RPP dapat digunakan sedikit revisi. Revisi dilakukan untuk penyesuaian tujuan pembelajaran dan indikator sehingga layak untuk diujicobakan dan sesuai terhadap pendekatan penemuan terbimbing, permasalahan yang diberikan atas dasar fenonema kehidupan seharihari/nyata. LKS dapat digunakan sedikit revisi. Revisi dilakukan untuk menyesuaikan langkahlangkah kegiatan pada LKS terhadap keterampilan proses yang akan dilatihkan sehingga layak untuk diujicobakan. Perbaikan juga dilakukan agar disesuaikan terhadap pendekatan penemuan terbimbing, permasalahan yang diberikan atas dasar fenonema kehidupan sehari-hari/nyata, materi yang disajikan harus dipastikan tidak salah konsep. MAS dapat digunakan sedikit revisi. Revisi dilakukan untuk menyesuaikan materi pada MAS terhadap keterampilan proses yang akan dilatihkan. Selanjutnya adanya konsep dan tulisan kurang sesuai pada MAS, sehingga harus diperbaiki sehingga layak untuk diujicobakan. THB dapat digunakan mengukur hasil belajar namun sedikit revisi. Adanya butir soal yang tidak sesuai dengan konsep maupun tujuan pembelajaran sehingga dilakukan revisi. Revisi dilakukan untuk menyesuaikan tujuan pembelajaran terhadap butir soal yang dikembangkan.

Berdasarkan hasil penilaian serta saran-saran yang diberikan oleh validator terhadap perangkat pembelajaran yang telah dikembangkan, silabus mendapat penilaian validator dengan kriteria sangat valid, hal ini menunjukkan komponen-komponen penyusun silabus sudah lengkap dan relevan terhadap pendekatan penemuan terbimbing untuk melatihkan keterampilan proses. Hasil validasi RPP juga menunjukkan komponen-komponen penyusun RPP sudah lengkap, relevan dengan KTSP, sesuai dengan pendekatan penemuan terbimbing untuk melatihkan keterampilan proses. Langkah-langkah dan aktivitas dalam pembelajaran penemuan terbimbing menekankan keterlibatan siswa secara aktif atau pembelajaran yang berpusat kepada siswa. Guru sebagai fasilitator yang memberikan bimbingan kepada siswa untuk melatihkan keterampilan proses. Hal ini sesuai dengan pendapat Bruner dalam Nur (2000) menyatakan bahwa pentingnya siswa terlibat aktif dalam pembelajaran dan meyakini bahwa pembelajaran yang terjadi sebenarnya melalui penemuan.

Hasil penilaian LKS oleh validator dengan kriteria valid, hal ini menunjukkan LKS relevan dan sesuai dengan pendekatan penemuan terbimbing untuk melatihkan keterampilan proses. LKS yang dikembangkan peneliti memiliki kelebihan yaitu menggunakan gambar yang berwarna dan bersifat komunikatif, memiliki petunjuk dan arahan yang jelas sehingga memudahkan siswa untuk mengerjakannya, isi materi tidak menyimpang dari materi yang diajarkan, pada kegiatan LKS dilakukan secara berkelompok agar tercipta interaksi dalam pembelajaran baik dengan guru maupun dengan siswa, Alat dan bahan yang digunakan dalam kegiatan pada LKS merupakan barang bekas yang banyak dijumpai dengan lingkungan siswa, Isi materi tidak menyimpang dari materi yang diajarkan.

Komponen kegiatan pada LKS tersebut sesuai dengan teori Vygotsky mengemukakan 
empat prinsip seperti yang dikutip oleh (Slavin, 2000: 256) yaitu: (1) pembelajaran sosial (social leaning). Pendekatan pembelajaran yang dipandang sesuai adalah pembelajaran kooperatif. Selanjutnya, Piaget dalam slavin (2011) menyatakan bahwa perkembangan kognitif bergantung pada seberapa jauh siswa aktif berinteraksi dengan lingkungannya. Ia menyatakan bahwa perkembangan kognitif terbentuk bukan hanya hasil kematangan organisme, bukan pula pengaruh lingkungan semata, melainkan hasil interaksi diantara keduanya. Sudirman (1991:203) yang menyatakan LKS merupakan salah satu bahan ajar sebagai sumber belajar yang membawa pesan untuk tujuan pengajaran dan kegiatan yang diupayakan untuk dikuasai siswa.

Berdasarkan hasil penilaian validator, MAS dengan kriteria valid, hal ini menunjukkan MAS relevan dan sesuai dengan pendekatan penemuan terbimbing untuk melatihkan keterampilan proses. Hasil analisis data kriteria kelayakan materi ajar siswa, menunjukkan bahwa materi ajar siswa tersebut berbeda dari buku-buku yang telah digunakan siswa selama ini. Adanya kelebihan tersebut antara lain di awal terdapat kalimat bertanya adalah untuk menumbuhkan rasa ingin tahu siswa sebelum masuk pada materi yang disajikan sehingga siswa akan menemukan konsep melalui MAS yang dikembangkan, materi siswa disusun sesuai dengan tingkat perkembangan siswa.

Komponen MAS tersebut sesuai teori Bruner yaitu belajar dengan penemuan dan pendapat arikunto dalam Djamarah dan Zain (1996:50) yang menyatakan bahwa materi ajar adalah salah satu bahan ajar yang merupakan unsur inti dalam kegiatan belajar mengajar yang harus disesuaikan dengan kebutuhan anak didik pada usia tertentu dan lingkungan tertentu pula. Kelebihan berikutnya yaitu gambar berwarna dan sesuai materi yang diajarkan serta adanya rangkuman dan daftar istilah yang memberikan informasi dan pengetahuan baru pada siswa.

THB mendapat penilaian oleh validator dengan kriteria valid dan sesuai dengan tujuan pembelajaran yang dikembangkan. Pada penelitian pengembangan ini dilakukan pengukuran hasil belajar siswa baik kemampuan kognitif maupun keterampilan proses siswa, sehingga dikembangkan Tes Hasil Belajar (THB) berupa THB kemampuan kognitif dan THB keterampilan proses siswa. THB kognitif dikembangkan 19 butir soal yang terdiri dari 14 butir bentuk pilihan ganda dan 5 butir bentuk uraian, sedangkan THB keterampilan proses terdiri dari 8 soal uraian. Seluruh butir soal dikembangkan berdasarkan jenjang kognitif soal dari C1-C6 dan tujuan pembelajaran yang telah dirumuskan serta keterampilan proses yang akan dilatihkan. Hal ini sesuai dengan pendapat Syaiful Bahri Djamarah dan Aswan Zain, (1997:120-121) mengungkapkan, bahwa untuk mengukur dan mengevaluasi tingkat keberhasilan belajar tersebut dapat dilakukan melalui tes prestasi belajar.

Tingkat keterbacaan materi ajar siswa merupakan tingkat pemahaman siswa terhadap materi ajar yang dikembangkan untuk mengukur kualitas MAS, yang dilakukan oleh seluruh siswa/responden untuk dijadikan sampel.

Analisis penilaian terhadap Tingkat keterbacaan materi ajar siswa diketahui rata-rata yaitu $34.67 \%$. Hal ini menunjukkan bahwa tingkat keterbacaan materi ajar siswa rendah dan sangat mudah dipahami oleh siswa.

Berdasarkan uraian di atas, sehingga dapat dikatakan perangkat pembelajaran yang dikembangkan berdasarkan masing-masing penilaian oleh validator, rata-rata termasuk dalam kategori valid sehingga layak digunakan pada ujicoba di kelas. Analisis persentase tingkat keterbacaan materi ajar siswa dapat disimpulkan tingkat keterbacaan materi ajar siswa rendah dan mudah dipahami oleh siswa.

Kriteria kedua, kelayakan sebuah perangkat yang baik menurut Nieeven (1999:125) yaitu adalah kepraktisan. Kepraktisan perangkat pembelajaran dapat dianalisis melalui keterlaksanaan RPP selama pembelajaran, Aktivitas siswa, dan hambatanhambatan selama proses pembelajaran yang diukur melalui pengamatan.

Hasil analisis pada keterlaksanaan RPP sangat baik dan diperoleh rata-rata KBM-1 $100 \%$, KBM-2 100\%, KBM-3 100\%. Keterlaksanaan RPP tersebut dapat dikatakan sangat baik karena skala keterlaksanaan $76 \%-100 \%$ dan Reliable karena nilai realibilitas telah melewati batas minimal yang ditetapkan yaitu $(r) \geq 0.75$. Hal ini menunjukkan guru telah melaksanakan seluruh tahapan atau sintaks pembelajaran berbasis pendekatan penemuan terbimbing. Adapun sintaks yang telah dikembangkan merupakan sintaks yang diadaptasi dari Eggen (2002) dan Kartawisastra, dkk. (1980).

Analisis hasil pengamatan terhadap aktivitas siswa dalam pembelajaran dengan pendekatan penemuan terbimbing untuk melatihkan keterampilan proses, diperoleh rata-rata aktivitas 
KBM-1 $93.14 \%$ dengan tingkat realibilitas 0.98, KBM-2 $92.57 \%$ dengan tingkat realibilitas 0.98 , KBM-3 93.90\% dengan tingkat realibilitas 0.98 . Aktivitas siswa dapat dikatakan sangat aktif karena rata-rata skala yang diperoleh setiap KBM $76 \%$ $100 \%$ dan reliable karena nilai realibilitas telah melewati batas minimal yang ditetapkan yaitu $(r) \geq$ 0.75 .

Berdasarkan uraian di atas dapat dikatakan bahwa perangkat pembelajaran berbasis penemuan terbimbing juga telah memenuhi kriteria kepraktisan, yang dibuktikan dengan keterlaksanaan RPP mencapai rata-rata $100 \%$ atau terlaksana sangat baik, Aktivitas siswa sangat tinggi berkisar 76\%-100\% , serta hambatan-hambatan yang ditemukan pada saat penelitian tidak terlalu banyak dan segera memiliki solusi. Hal ini membuktikan bahwa perangkat pembelajaran telah memenuhi kriteria kepraktisan.

Kriteria ketiga, kelayakan sebuah perangkat yang baik menurut Nieeven (1999:125) yaitu adalah keefektifan. Keefektifan perangkat pembelajaran dapat dianalisis melalui keterampilan proses sains pada proses pembelajaran, hasil belajar siswa dan respon siswa.

Analisis hasil belajar siswa dibagi menjadi dua yaitu hasil belajar kognitif dan hasil belajar keterampilan proses. Hasil belajar siswa merupakan salah satu indikator kelayakan perangkat pembelajaran yang dikembangkan. Ketuntasan individu tujuan pembelajaran dan KBM dengan menerapkan pendekatan penemuan terbimbing untuk melatihkan keterampilan proses dapat dikatakan tuntas apabila semua proporsi tujuan pembelajaran besarnya $\geq 75$ sesuai dengan standar ketuntasan SDN Pagerwojo. Ketuntasan hasil belajar secara klasikal apabila $85 \%$ dari keseluruhan siswa mencapai proporsi tujuan pembelajaran besarnya $\geq 75$.

Jenis soal pelatihan keterampilan proses pada penelitian ini meliputi : keterampilan proses mengamati, mengukur, menginferensi, memprediksi, interpretasi, hipotesis, pengkomunikasian dan menyimpulkan. Jumlah soal untuk mengukur keterampilan proses sebanyak 8 butir sesuai dengan keterampilan proses yang diujicobakan.

Pada pretest diketahui dari 25 siswa belum ada yang tuntas dari standar ketuntasan yang ditetapkan yaitu 75 baik ketuntasan secara individu maupun secara klasikal yang dibuktikan dengan rata-rata ketuntasan kelas pada pretest hanya mencapai 43.3 dengan ketuntasan 0\%. Hal ini dikarenakan siswa baru mengenal keterampilan proses, selama ini siswa tidak pernah dikenalkan terhadap keterampilan proses dalam pembelajaran.

Selanjutnya, setelah diberikan pembelajaran berorientasi penemuan terbimbing dilakukan postest, ketuntasan secara individu maupun secara klasikal dari 25 orang siswa mengalami peningkatan, dengan rata-rata 84 dan persentase ketuntasan $92 \%$ yang diperoleh menunjukkan bahwa keterampilan proses secara individu maupun klasikal telah tuntas. Adapun besarnya peningkatan / N-Gain skor pada pretest-postest yang telah dilakukan dikategorikan tinggi dengan rata-rata gain 0.72 . Hal ini menjelaskan bahwa pembelajaran penemuan terbimbing mempunyai efek yang positif terhadap keterampilan proses siswa.

Meskipun keterampilan siswa mengalami peningkatan, namun dalam proses pelatihan keterampilan proses siswa masih ada hambatan yaitu siswa masih merasa bingung tentang hipotesis. Hal ini dapat dilihat dari hasil postest masih ada 2 orang siswa yang belum tuntas.

Tingkat sensitivitas untuk masing-masing butir soal yang digunakan dalam ujicoba. Rata-rata sentivitas dari 8 butir soal yang terdiri dari soal uraian diperoleh 0.43 yang berarti tingkat sensitivitas keleluruhan butir soal dikategorikan sedang dan peka terhadap pembelajaran. Hal ini sesuai pendapat Aiku (1997:69), butir soal dikatakan baik apabila sensitivitas antara 0 dan 1 . Kriteria yang dipakai untuk menyatakan bahwa butir soal peka terhadap pembelajaran jika $\mathrm{S} \geq 0$, 30.

Analisis hasil belajar kognitif siswa pada pretest dari 25 siswa, hanya ada 3 orang yang tuntas dari standar ketuntasan yang ditetapkan yaitu 75 , yang dibuktikan dengan rata-rata ketuntasan kelas pada pretest hanya mencapai 57.13 dengan persentase ketuntasan $12 \%$. Selanjutnya, setelah diberikan pembelajaran berorientasi atau posttest penemuan terbimbing, ketuntasan secara individu maupun secara klaksikal dari 25 orang siswa mengalami peningkatan dan tuntas semua, dengan rata-rata 90.36 dan persentase ketuntasan 100\% yang diperoleh menunjukkan bahwa hasil belajar secara individu maupun klasikal telah tuntas. Adapun besarnya peningkatan / N-gain skore pada pretes-postest yang telah dilakukan dikategorikan tinggi dengan Rata-rata gain 0.93. Hal ini menjelaskan bahwa pembelajaran penemuan terbimbing mempunyai efek yang positif terhadap 
kemampuan kognitif siswa. Ketuntasan siswa menunjukkan bahwa pembelajaran berbasis pendekatan penemuan terbimbing untuk melatihkan keterampilan proses cocok dan sangat baik digunakan untuk mengajar pada materi gaya.

Rata-rata sentivitas dari 19 butir soal yang terdiri dari 14 soal bentuk pilihan ganda yaitu 0.25 kategori rendah dan 5 soal uraian diperoleh 0.57 kategori sedang dan peka terhadap pembelajaran. Hal ini sesuai pendapat menurut Aiku (1997:69), butir soal dikatakan baik apabila sensitivitas antara 0 dan 1 . Kriteria yang dipakai untuk menyatakan bahwa butir soal peka terhadap pembelajaran jika $S$ $\geq 0,30$.

Hasil validitas empiris butir soal posttest THB kognitif dan THB keterampilan proses yang dihitung dengan program SPSS yaitu valid karena nilai item soal berada di atas nilai signitifikansi dari 25 orang siswa yaitu 0.381. Butir soal juga dinyatakan reliable karena setiap butir soal memiliki nilai (r) pada Alpha Cronbach di atas 0.75 .

Analisis dilakukan dengan cara memberikan angket yang berisi 25 butir pernyataan sesuai dengan tingkat kesetujuan masing-masing siswa. Respon siswa terhadap pembelajaran diperoleh rata-rata persentase dari 25 orang siswa sebagai responden yaitu $85.92 \%$. Berdasarkan hasil persentase tersebut dapat dikategorikan bahwa tingkat respon siswa sangat baik dan positif terhadap pembelajaran menggunakan pendekatan penemuan terbimbing untuk melatihkan keterampilan proses. Menurut pendapat Piaget yang dikutip oleh Nur (2004) bahwa proses perkembangan kognitif ikut ditentukan oleh lingkungan belajar siswa. Jika lingkungan siswa merupakan lingkungan yang aktif, maka kognitif siswa akan terpola untuk mampu menguasai konsep dan memecahkan masalah dengan cepat.

Hasil penyelidikan rata-rata setiap kelompok mendapat nilai di atas 75, sehingga dapat dikatakan tuntas. Siswa telah mampu melakukan kegiatan penyelidikan menggunakan keterampilan proses melalui bimbingan guru.

Berdasarkan uraian di atas, maka dapat diketahui bahwa hasil keterampilan proses dan kognitif siswa telah mencapai ketuntasan $100 \%$, Respon siswa positif terhadap perangkat pembelajaran menggunakan pendekatan penemuan terbimbing, $85.92 \%$. Hal ini menunjukkan bahwa perangkat pembelajaran yang dikembangkan telah memenuhi kriteria keefektifan. Sehingga sangat layak untuk untuk melatihkan keterampilan proses sains di kelas IV SD khususnya pada materi gaya.

Berdasarkan hasil penelitian didapatkan temuan yaitu perangkat pembelajaran yang dikembangkan berdasarkan pendekatan penemuan terbimbing telah layak untuk melatihkan keterampilan proses sains siswa sekolah dasar pada materi Gaya. Hal ini didukung dari validitas perangkat pembelajaran yang valid dan reliable, keterbacaan materi ajar siswa yang dikembangkan sangat mudah dipahami oleh siswa. Perangkat pembelajaran yang dikembangkan dikatakan praktis, karena didukung oleh keterlaksanaan Rencana Pelaksanaan Pembelajaran yang sangat baik, aktivitas siswa selama pelaksanaan pembelajaran sangat aktif. Perangkat pembelajaran yang dikembangkan dikatakan efektif, karena didukung oleh hasil belajar kognitif dan keterampilan proses sains siswa yang meningkat dan tuntas secara klasikal serta respon siswa terhadap pembelajaran sangat positif.

Secara keseluruhan perangkat pembelajaran berbasis pendekatan penemuan terbimbing untuk melatihkan keterampilan proses yang dikembangkan dinilai telah memenuhi seluruh kriteria sebuah perangkat pembelajaran yang baik. Seperti menurut Nieveen (1999:125), perangkat pembelajaran yang baik jika memenuhi kriteria kevalidan, kepraktisan dan keefektifan.

Kelayakan perangkat pembelajaran tersebut didukung melalui validasi oleh 2 orang validator yang ahli di bidang perangkat pembelajaran maupun materi. Hal ini juga sesuai dengan penelitian terdahulu yang dilakukan oleh Handayani.S.A (2012). Hasil penelitian menyatakan pembelajaran penemuan terbimbing serta perangkatnya efektif meningkatkan hasil belajar dan keterampilan proses sains siswa pada konsep sistem pernapasan. Selanjutnya, Pembelajaran penemuan terbimbing dapat melatihkan keterampilan proses dan memberi peluang kepada siswa melakukan proses berpikir untuk menemukan konsep. (Lutfiandari.A, 2013).

\section{PENUTUP}

Berdasarkan temuan, disimpulkan bahwa perangkat pembelajaran berbasis pendekatan penemuan terbimbing yang dikembangkan layak untuk melatihkan keterampilan proses serta dapat meningkatkan hasil belajar IPA materi gaya pada siswa kelas IV SD. 
Berdasarkan diskusi hasil penelitian dan temuan selama penelitian, maka disarankan dalam menerapkan pembelajaran berbasis pendekatan penemuan terbimbing untuk melatihkan keterampilan proses sebaiknya perlu dipersiapkan terlebih dahulu mengenai langkah-langkah pembelajarannya serta memperhatikan alokasi waktu agar memperoleh hasil yang maksimal.

\section{DATAR PUSTAKA}

A.M., Sardiman. (2010). Interaksi dan Motivasi Belajar Mengajar. Jakarta: PT Rajagrafindo Persada

Abruscato, J. (1996). Teaching Children Science a Discovery Approach. Massuchusset : Allyn \& Bacan.

Afandi, M. dan Badarudin. (2011). Perencanaan Pembelajaran. Bandung: Alfabeta.

Anderson, L.W. \& David R.K. ( 2001).A Taxonomy for Learning and Teaching and Assessing: A Revision of Bloom's Taxonomy of Educational Objectives

Arikunto, S. (2006). Prosedur Penelitian Suatu Pendekatan Praktik, Ed Revisi VI. Jakarta : Penerbit PT Rineka Cipta.

B. Suryosubroto. (2002). Proses Belajar Mengajar Di Sekolah. Jakarta : Rineka Cipta

Badan Standar Nasional Pendidikan. (2006). Standar Isi Kurikulum Tingkat Satuan Pendidikan. Jakarta: Departemen Pendidikan Nasional.

Blosser, E., P. (1973). Handbook Of Effective Questioning Techniques. The Ohio States University Columbus. Ohio

Borich, G.D. (1994). Observation Skills for Effektive Teaching. New York : Macmillan Publishing Company.

Suryosubroto. (2002). Proses Belajar Mengajar Di Sekolah. Jakarta : Rineka Cipta

Carin, A.A and Robert B.S. (1993). Teaching Science Trought Discovery $7^{\text {th }}$ Edition. New York : MacMillan Publishing Company

Chiappetta, E.L dan Koballa.T.R. (2010). Science Instruction In The Middle and Secondary Schools Developing Fundamental Knowledge and Skills. Pearson Education,Inc

Cohen, M.T. (2008). The Effect of Direct Instruction versus Discovery Learning on the Understanding of Science Lessons by Second Grade Students. NERA Conference Proceedings 2008. Paper 30. http://digitalcommons.uconn.edu/nera_2008/30

Cooney, and Davis. (1975). Dynamics Of Teaching Secondary School Mathematics. U.S.A : Houghton Mifflin Company

Darmodjo, H. dan Kaligis, J.R.E. (1992). Pendidikan IPA 2. Jakarta: Departemen Pendidikan dan Kebudayaan.

Depdiknas. (2004). Kurikulum : Standar Kompetensi Mata Pelajaran SAINS SD/MI. Jakarta : Pusat Kurikulum Balitbang Depdiknas.

Devi, K.P., Sofie.R.R., dan Khairuddin. (2009). Pengembangan Perangkat Pembelajaran. Bandung: Pusat Pengembangan dan Pemberdayaan Pendidik dan Tenaga Kependidikan IPA.

Devi, K.P.(2010). Keterampilan Proses dalam Pembelajaran IPA untuk Guru SMP.Jakarta : Pusat Pengembangan dan Pemberdayaan Pendidikdan Tenaga Kependidikan IPA (P4TK).

Dhari. (1998). Metode Pembelajaran. Malang: Depdikbud.

Dick, W., Carey, L. and Carey, J. (2005). The Systematic Design of Instruction. Boston, MA; Pearson.

Dimyati dan Mudjiono. (2009). Belajar dan Pembelajaran. Jakarta: Rineka Cipta

Djaali. 2008. Psikologi Pendidikan. Jakarta : CV Pendoman Ilmu Jaya

Djamarah, S.B dan Aswan Z. (1997). Strategi Belajar Mengajar. Jakarta: Rineka Cipta

Eggen, D.P.K. (2012). Strategi dan Model Pembelajaran. Jakarta: Indeks.

Gholamian, A. (2013). Studying the Effect of Guided Discovery Learning on Reinforcing the Creative Thinking of Sixth Grade Girl Students in Qom during 2012-2013 Academic Year. Journal of Applied Science and Agriculture, 8(5) October 2013, Pages: 576-584. American-Eurasian Network for Scientific Information (AENSI) Journals, home page: www.aensiweb.com/jasa/index.html

Gulo, W.(2002). Strategi Belajar Mengajar. Jakarta : Grasindo

Hamalik, Oemar. (2001). Proses Belajar Mengajar. Jakarta : Bumi Aksara

Handayani, S.A. (2012). Pengembangan Perangkat Pembelajaran IPA Berbasis Metode Penemuan Terbimbing (Guided Discovery) untuk Melatihkan Keterampilan Proses 
Sains.(Tesis Magister Pendidikan tidak dipublikasikan).Unesa.

Hudojo, H. (1984). Metode Mengajar Matematika. Jakarta: Depdikbud-Dirjen Dikti.

Hikmawati. (2008). Hubungan Antara Minat Baca dengan Prestasi Belajar Siswa Kelas VIII Di SLTP Pahlawan Nasional Medan Tahun Ajaran 2007/2008. Medan :(Tesis magister pendidikan tidak dipublikasikan). UNIMED

Ibrahim, M. (2005). Pembelajaran Berdasarkan Masalah.Surabaya : University Press.

Ibrahim, M. (2010). Dasar-dasar Proses Belajar Mengajar.Surabaya : University Press.

Kardi, S dan Nur, M. (2003). Pengantar Pengantar pada Pembelajaran dan Pengelolaan Kelas. Surabaya : Uni press

Kartawisastra, H. Una, Abimanyu. Soli. (1999). Penemuan sebagai Metode Belajar Mengajar. Jakarta: Proyek Pengembangan Pendidikan Guru (P3G) Depdikbud.

Karuru, P. (2002). Penerapan Keterampilan Proses dalam Setting Pembelajaran Kooperatif untuk Meningkatkan Kualitas Belajar SLTP.

Trowbridge Leslie W., Bybee, Rodger W. (1990) Becoming a Secondary School Science Teacher. Merrill Publishing Company : University of Virginia

Lutfhiandari, A. (2013). Pengembangan Perangkat Pembelajaran Berdasarkan Pendekatan Penemuan Terbimbing untuk Melatihkan Keterampilan Proses Siswa SMP.(Tesis magister pendidikan tidak dipublikasikan). Universitas Negeri Surabaya.

Marzano, R.J. (1992). A Different Kind of Classroom, Teaching with Dimensions of Learning. Alexandria.VA: ASCD

Mulyasa, E.(2006). Kurikulum Tingkat Satuan Pendidikan. Bandung: Remaja Rosdakarya.

Nur, M. dan Wikandari, P.R. (2008).Pengajaran Berpusat kepada Siswa dan Pendekatan Konstruktivis dalam Pengajaran. Surabaya : University Press.

Purwanto. (2011). Evaluasi Hasil Belajar.Yogyakarta: Pustaka Pelajar

Ratumanan, Taney Gerson. (2002). Belajar dan Pembelajaran. Surabaya : Unesa, University Press

Richard E. Mayer. (2004). Should There Be a Three Strikes Rule Against Pure Discovery Learning? The Case for Guided Methods of Instruction. Copyright 2004 Journal by the American Psychological Association,
Inc.Vol. $\quad 59, \quad$ No. $\quad 1, \quad 14-19$ DOI: 10.1037/0003-066X.59.1.14

Mc. Greal. (2004). Online Education Using Learning Objects. Stoodleigh, Devon : Florence Production Ltd.

Rose Amnah Abd Rauf. (2013). Journal :Inculcation of Science Process Skills in a Science Classroom. Faculty of Education, Universiti Malaya (UM), Kuala Lumpur 50603, Malaysia. Asian Social Science; Vol. 9, No. 8; 2013 Published by Canadian Center of Science and Education.

Seel dan Richey. (1994). Instructional Technology. AECT. Washington, DC.

Setya, AN. (2010). Pengembangan Perangkat Pembelajaran Berdasarkan Pendekatan Penemuan Terbimbing untuk Melatihkan Keterampilan Berfikir Siswa Sekolah Dasar.(Tesis magister pendidikan tidak dipublikasikan). Universitas Negeri Surabaya.

Siswoyo, D.(2011). Ilmu Pendidikan. Yogyakarta: UNY Press

Slameto. (2003). Belajar dan Faktor-Faktor yang Mempengaruhinya. Jakarta: Rineka Cipta.

Slavin, Robert E. (2011). Psikologi Pendidikan (Teori dan Praktik) Jilid 2. Jakarta: PT. Indeks.

Suhadi. (2007). Petunjuk Perangkat pembelajaran Surakarta : Universitas Muhammadyah.http://anrusmath.wordpress. com/2007/09/29/perangkatpembelajaran.(dia kses 22 April 2015).

Sund, R.B \& Trowbridge, L. (1973). Teaching Science Inkuiri by In The Secondary Schools.Ohio : Charles E. Merril Publishing Co.

Trianto. (2010). Mendesain Model Pembelajaran Inovatif-Progresif. Jakarta : PT. Kencana.

Udo, Mfon Effiong. (2010). Effect of GuidedDiscovery, Student- Centred Demonstration and the Expository Instructional Strategies on Students' Performance in Chemistry (Pp. 389-398) An International MultiDisciplinary Journal, Ethiopia Vol. 4 (4), Serial No. 16, October, 2010 Department of Science Education, University of Uyo, Uyo Cross River State, Nigeria

Zulfiani. (2009). Strategi Pembelajaran Sains. Jakarta: Lembaga Penelitian UIN. 